\title{
Frederick II of Hohenstaufen's Australasian cockatoo: a symbol of detente between East and West and evidence of the Ayyubid Sultanate's global reach.
}

\author{
Heather Dalton, Jukka Salo, Pekka Niemelä and Simo Örmä. 1
}

The depiction of an Australasian cockatoo in Andrea Mantegna's Madonna della Vittoria, completed in Mantua in 1496, has recently been discussed by Heather Dalton in her 2014 article, 'A Sulphur-crested Cockatoo in fifteenth century Mantua: Rethinking symbols of sanctity and patterns of trade. ${ }^{2}$ Dalton examined the presence of this parrot in Mantegna's altarpiece and concluded that the image revealed 'the complexity and range of Southeast Asian trading networks prior to direct European contact' as well as confirming the interests and purchasing power of Mantegna and his patrons, the Gonzagas. She posited that it was very likely that Mantegna had a live bird as a model, suggesting that as 'cockatoos are known for their longevity, gregariousness and ability to live happily with humans', a young cockatoo could have made the long journey from 'east of the Wallace Line to Europe'. In support of this she noted that in the thirteenth century, 'the Sultan of Babylon sent a White Cockatoo from Indonesia to the leader of the Sixth Crusade, the Holy Roman Emperor Frederick II'. ${ }^{3}$ The evidence for this is in Emperor Frederick II's book on ornithology and falconry, De Arte Venandi cum Avibus (The Art of Hunting with Birds). ${ }^{4}$

De Arte was written in Latin by Frederick or a scribe under his direction between 1241 and 1244 and is thought to have been based on a translation of two Arabic texts on falconry; the Kitāb al-Mutawakkilì, dedicated to the Abbasid Caliph al-

Mutawakkil, and a manuscript by Adham and Ghițrif. ${ }^{5}$ Although Frederick's original manuscript was lost in 1248 at the siege of Parma, six volumes of material, including drafts and fragments relating to the lost manuscript, survived at the emperor's Apulian castles. Ten years after the loss of the original manuscript, and eight years after Frederick's death, his son, Manfred began the painstaking exercise of recreating his father's work using this material. ${ }^{6}$ In 1266 Manfred was killed at the battle of Benevento and his still incomplete De Arte was taken as plunder, ending up in the possession of Jean II de Dampierre-Saint-Dizzier (commonly known as John of Flanders). By the mid sixteenth century, the Nuremburg intellectual Joachim Camararius the younger owned the manuscript and in 1596 Markus Welser published a printed edition in Augsburg. In 1622 the Duke of Bavaria, Maximilian I, presented the original manuscript to Gregory XV to be included in the Bibliotheca Palatina, then

\footnotetext{
${ }^{1}$ The authors thank Leena Laiho (University of Turku) for her advice and translations, and Anne Dunlop (University of Melbourne), Campbell Macknight (Australian National University) and the anonymous reviewers for their much-appreciated feedback.

${ }^{2}$ Heather Dalton, 'A Sulphur-crested Cockatoo in fifteenth century Mantua: Rethinking symbols of sanctity and patterns of trade.' Renaissance Studies 28/5 (2014), 676-694. The term 'Australasia' was coined by Charles de Brosses in Histoire des navigations aux terres australes (1756). It includes Australia, New Zealand, and neighbouring islands in the South Pacific, including Melanesia.

${ }^{3}$ Dalton, 'A Sulphur-crested Cockatoo', p. 689.

${ }^{4}$ Frederick II, De Arte Venandi cum Avibus, Codex Ms. Pal. Lat 1071, Bibliotheca Apostolica Vaticana, Rome. English translation in Casey A. Wood and F. Marjory Fyfe, The Art of Falconry (Stanford: Stanford University Press, 1943), pp. 58-59.

${ }^{5}$ Virgilio Martínez Enamorado, 'Falcons and Falconry in Al-Andalas,' Studia Orientalia III (Societas Orientalis Fennica, 2011): pp. 159-183.

${ }^{6}$ Because Manfred calls himself 'rex' we know that this codex was executed between August 1258 (when he was crowned king in Palermo) and $26^{\text {th }}$ of February 1266 when he died.
} 
in Heidelberg. ${ }^{7}$ The manuscript, now in Rome and known as 'Codex Ms. Pal. Lat 1071', is made up of Manfred's two-volume, 111 folio adaptation of the De Arte. ${ }^{8}$ It is the work of a single hand, except for folio 74. Amongst the nine hundred marginal illustrations of birds, animals, falconers, perches and falconry equipment are four coloured drawings of the white cockatoo gifted to Frederick II. ${ }^{9}$

Codex Ms. Pal. Lat 1071 - the manuscript now in the Vatican Library - is one of only two surviving versions of Frederick's work containing images as well as textual references to the cockatoo. The other - now in the National Library of France - is a French translation of Manfred's manuscript, prepared for Jean II de Dampierre-SaintDizzier by Simon d'Orleans circa $1300 .{ }^{10}$ The images of the cockatoo in the French manuscript are copies of those in Codex Ms. Pal. Lat 1071, although their juxtaposition to other birds is slightly different and they are more upright and wooden in appearance with slightly exaggerated beaks. ${ }^{11}$ Because the four images in the Vatican manuscript have rarely been reproduced in print, few people are aware of their existence. This may be because many scholars have relied on Casey Albert Wood and Florence Marjorie Fyfe's 1943 English translation of all six books of the De Arte. ${ }^{12}$ Although Wood and Fyfe included many illustrations from the Codex Ms. Pal. Lat 1071, they did not include those of the cockatoo. This article, the result of an international collaboration between historians and zoologists, aims to focus attention on the fact that Australasian cockatoos were present in the Middle East in the medieval period and that one, identified as a Sulphur-crested or Yellow-crested Cockatoo, reached Europe in the mid thirteenth century. The article is divided into three parts. Firstly, we review previous identifications of the cockatoo, describe the images and explain our identification. Both our description of the drawings and the identification of the cockatoo are the result of a first-hand study of the original Codex Ms. Pal. Lat 1071 in the Vatican Library. Secondly, we explore the political and religious landscape, courtly interests, and diplomatic relationships that led the 'Sultan of Babylon' to give the cockatoo to Frederick II. Thirdly, we consider the emerging trade routes that brought this cockatoo to the Apennine Peninsula two and a half centuries before Mantegna portrayed a bird of the same species in his altarpiece.

\section{The images in Codex Ms. Pal. Lat 1071}

Several natural scientists and ornithologists have previously recognised that the images of Frederick's cockatoo in Codex Ms. Pal. Lat 1071 depict an Australasian species; describing it as a White Cockatoo, also known as an Umbrella Cockatoo, (Cacatua alba), a Sulphur-crested Cockatoo (Cacatua galerita), or a Yellow-crested

\footnotetext{
${ }^{7}$ For discussion of the 6-volume and 2-volume manuscripts and printed books, see Wood and Fyfe, The Art, Ivii - xcv; Charles H. Haskins, 'The 'De Arte Venandi cum Avibus' of the Emperor Frederick II,' The English Historical Review 36/143 (1921), 334-355.

${ }^{8}$ For the move of the Bibliotheca Palatina from Heidelberg to Rome see: http://digi.ub.uniheidelberg.de/en/bpd/bibliotheca_palatina/geschichte.html, accessed 30 September 2017.

${ }^{9}$ Wood and Fyfe, The Art, pp. Iii - Ixx.

${ }^{10}$ Livre de l'art de chasser aux oiseaux

Frédéric II, Traité de Fauconnerie traduction française, faite à la demande de Jean, sieur de Dampierre et de Saint-Dizier, et de sa fille Isabelle. Ms. Fr. 12400, Bibliothèque nationale de France, Paris.

${ }^{11}$ For a brief discussion regarding Simon d'Orleans' copying of these images, see Jonathan J. G. Alexander, Medieval Illuminators and their Methods of Work (New Haven and London: Yale University Press, 1992), p.135.

${ }^{12}$ For a detailed discussion of the 6-volume and 2-volume manuscripts and printed books, see Wood and Fyfe, The Art, pp. Ivii - xcv.
} 
Cockatoo, also known as a Lesser Sulphur-crested Cockatoo, (Cacatua sulphurea). ${ }^{13}$ In his 1980 German-language study of Frederick's 'Falkenbuch', C.A. Willemsen suggested the cockatoo was a 'Molukkenkakadu (Kakatoe cacatua)'. Three years later, W.B. Yapp identified it simply as 'a white cockatoo, which does not occur further west than the Moluccas'. More recently, in 2008, Kinzelbach, a well-known authority on the De Arte, reviewed these identifications, confirming that the bird was a 'Gelbhaubenkakadu' - a member of the Cacatua galerita - C. sulphurea species group - in other words a Suphur-crested or a Yellow-crested Cockatoo. ${ }^{14}$ These identifications are varied because, while some scholars simply cited previous descriptions, others relied on facsimile versions, colour photographs, or, as in the case of Wood and Fyfe and Williamson, monochrome photographs of the originals.

Another source of confusion has been that Erwin Stresemann, in his 1951 review of ornithology from Aristotle to the modern times, referred to Frederick's cockatoo as a 'weissen Haubenkakadu'. ${ }^{15}$ This was mistranslated as 'White Cockatoo', and henceforth taken to refer to the species White Cockatoo (Cacatua alba). This small but significant translation error has subsequently been repeated in several sources in the twenty-first century, including Boehrer's Parrot Culture (2004) and Chansigaud's History of Ornithology (2009). ${ }^{16}$

In the Codex Ms. Pal. Lat. 1071, the drawings are in the margins, generally coloured, and always positioned beside the text they illustrate. They appear to have been drawn from specimens present in Frederick's various castles. As Richard of Germano, Frederick's notary, reported that his master could draw, it is likely the emperor had a hand in their composition. While some may been conceived of or even sketched by Frederick, others would have been collaborations with more than one artist under the auspices of either Frederick or Manfred. ${ }^{17}$ Although the birds are not shown to scale, the illustrations are detailed enough to allow the identification of the species in most cases. There are images of just two types of parrot: a green parrot, labelled 'psittacus uiridis', which could be a Rose-ringed Parakeet (folio $29 \mathrm{v}$ ); and the cockatoo that is the focus of this article (folios $18 \mathrm{v}, 20 \mathrm{r}, 20 \mathrm{v}$ and $26 \mathrm{v}$ ). ${ }^{18}$ The drawings of the cockatoo

\footnotetext{
${ }^{13}$ Species classifications: White Cockatoo (Cacatua alba), Statius, P.L. Müller (1776); Yellow-crested Cockatoo (Cacatua sulphurea), Gmelin 1788; Sulphur-crested Cockatoo (Cacatua galerita), Latham 1790. For bird classification/naming used in this article see (http://www.worldbirdnames.org/ May 2017).

14 C.A.Williamson, Das Falkenbuch Kaiser Friedrichs II. Nach der Prachthandschrift in der Vatikanischen Bibliothek (Dortmund: Harenberg Verlag, 1980). 2nd edition (1986), 302; W.B. Yapp, 'The illustrations of birds in the Vatican manuscript of De arte venandi cum avibus of Frederick II,' Annals of Science 40/6 (1983), 597-634; Ragnar Kinzelbach, 'Modi auium - Die Vogelarten im Falkenbuch des Kaisers Friedrich II', in Kaisers Friedrich II 1194-1250: Welt Und Kultur Des Mittelmeerraums, eds Karen Ermete, Mamoun Fansa and Carsten Ritzau (Mainz: Philipp Von Zabern, 2008), vol. 2, pp. 62-135; Also see Rupert Gerritsen, 'Birds in Early Australian History', Australia on the Map (1606-2006) Project, available from rupertgerritsen.tripod.com/pdf/published/Birds_in_Early Australian_History.pdf, accessed 03 October 2016.

${ }^{15}$ Erwin Stresemann, Die Entwicklung der Ornithologie von Aristoteles bis zur Gegenwart (Berlin: Peters, 1951), pp. 25-26.

${ }^{16}$ Valerie Chansigaud, History of Ornithology (London: New Holland Publishers, 2009); Bruce Thomas Boehrer, Parrot Culture (Philadelphia: University of Pennsylvania Press, 2004).

${ }^{17}$ Wood and Fyfe, The Art, I ii - 1xx, xxxviii; Haskins, 'The 'De Arte', p. 339.

${ }^{18}$ Yapp, 'The illustrations of birds', pp. 597-634; Kinzelbach, 'Modi auium,' vol. 2, pp. 62-135. Explore the full manuscript and the images of the cockatoo in context at the Digital Vatican Library at: https://digi.vatlib.it/search?k_f=3\&k_v=De+Arte+Venandi+cum+Avibus or http://digi.ub.uniheidelberg.de/diglit/bav_pal_lat_1071. The French copy made for Jean II de Dampierre-Saint-Dizzier can be accessed at: http://gallica.bnf.fr/ark:/12148/btv1b525068331.
} 
are in a stereotypic pattern characteristic of the marginal illustrations throughout the book. All four images, shown in figures $1-4$ at the end of this article, are very similar in pose.

Above the cockatoo in figure 1 (folio 18v) is the label 'cristas' (crests). This drawing accompanies a text that begins: 'The majority of birds with feathered heads have no crests' and then goes on to describe exceptions:

'Alie habent plumas ellevatas in medio capitis ad modum criste, ut upupe, cozardi et modus quidam psitacorum, qui apportantur de India. De hoc enim misit Nobis soldanus Babilonie <unam > albam pennis et plumis superioribus, subterioribus vero tendentem ad croceum collorem.'

'Other birds sport a crest of feathers, among them the hoopoe, the horned lark, and certain parrots imported from India. One of the latter was sent to us by the Sultan of Babylon; it had white feathers and quills, changing to yellow under the sides. ${ }^{19}$

As Jean Givens points out in Observation and Image Making in Gothic Art, images of plants and animals presumed to have been drawn from life are now understood to have been copies from earlier models. ${ }^{20}$ On the other hand, as W.B Yapp points out in his 1983 article, this image of the cockatoo, as well as the other three, 'are some of the few drawings in the book that we can be sure were made from an actual specimen'. ${ }^{21}$ Yapp is right in that Frederick's reference to the cockatoo being a gift points to him having a live specimen in his possession. Yet, Codex Ms. Pal. Lat 1071 is a compilation of drafts for and/or surviving fragments of Frederick's original manuscript, as well as new images commissioned by Manfred. This means that although it is possible that one or more of the images was one of Frederick's surviving drawings or even a drawing of the live cockatoo commissioned by Manfred, it is more likely that they are copies of draft sketches or badly damaged fragments of Frederick's manuscript. ${ }^{22}$

The cockatoo in figure 3 (folio 20v), labelled 'psittacus' (parrot), illustrates a discussion about the tongues of birds. In it, the writer explains how white parrots in particular are able to imitate human speech:

'Set que habent linguam carnosam et crossam sunt que nituntur imitari in gu] ure suo voces humanas, quas sepius audiunt, ut corvorum modi et picarum, et psytacorum viridium modus, et maxime modus alborum.'

'Birds with a thick and fleshy tongue endeavour to imitate the human voice and words they hear most frequently. These are chiefly the raven, the magpie family, and, still more frequently, the parrots of the green variety and even more often those of the white species. ${ }^{23}$

\footnotetext{
${ }^{19}$ Codex Ms. Pal. Lat 1071, fol. 18v. English translation in Wood and Fyfe, The Art, pp. 58-59.

${ }^{20}$ Jean Givens, Observation and Image Making in Gothic Art (New York: Cambridge

University Press, 2005).

${ }^{21}$ Yapp, 'The illustrations of birds', p. 612.

${ }^{22}$ Dalton, 'A Sulphur-crested Cockatoo', p. 689. Note that as Sulphur-crested Cockatoos (Cacatua galerita) are known to live up to 120 years in captivity, and Yellow-crested Cockatoos (Cacatua sulphurea) up to eighty years, it is feasible that Manfred had custody of the cockatoo gifted by the sultan.

${ }^{23}$ Wood and Fyfe, The Art, p. 77.
} 
Images of a magpie and raven on folio $21 \mathrm{r}$ further illustrate this point. The cockatoo in figure 4 (folio 26v) is also labelled 'psittacus' and is accompanied by a 'bistarda' (a bustard or Great Bustard) and a 'phunerius' (a brown speckled bird, probably a female blackbird). The cockatoo in figure 2 (folio 20r) is not labelled. Nor are the herons, pigeons, crane, and pelican on that folio.

All four illustrations show a bird with the clearly defined feet of a parrot, with two toes facing forward. Cockatoos have four toes, which is not always obvious when they are on the ground and therefore it looks as if Frederick's cockatoo has just one backward facing toe. In all, the bird is predominantly white to yellowish white, with the yellow being most intense on the flanks of the body. The colour of the plumage, combined with the shape of the beak and the recumbent crest, confirms what the text suggests - that this was a cockatoo. The images in figures 1 and 2 are more detailed than those in figures 3 and 4 . While the cockatoo in figure 4 has lost much of its colour and the details are indistinct, the other three images are quite clear. The two more detailed drawings feature a mysterious black dot on the upper wing line - a feature that does not exist in cockatoos. The same black dot is visible on other images of light coloured birds, suggesting that they were probably copied from Frederick's original book, using the dot as a central drafting point. While in figure 1 the wings are lighter in colour than the body plumage, in figures 2, 3 and 4 the yellow is clearly visible on the bird's back, and in 2 and 3, both the scapulars and wing coverts have a yellow tinge. In the original Latin text, this colour is referred to as 'croceum' - a saffron yellow colour. ${ }^{24}$ All four birds have a recumbent crest, which is yellow in figure 1, white in figure 2, and bicoloured in figures 3 and 4 . This colour range and the fact that the tip of the crest is narrow and curls upwards confirm that these drawings are either of a Sulphur-crested Cockatoo or Yellow-crested Cockatoo, rather than a Salmon-crested Cockatoo or White Cockatoo (whose recumbent crest has a blunt, wedge shaped tip).

The authors examining the images of Codex Ms. Pal. Lat 1071 in the Vatican Library were able to discern distinct details. For example, while the cockatoos in all four images have grey beaks and feet, the beaks in figures 1,2 and 3 darken to a dark lead grey on the ridge of the upper beak. In figure 1 in particular, the area between the bird's eyes and beak, known as the loral, is almost black. ${ }^{25}$ While the iris is clearly red in figures 2 and 3, flecks of red pigment remain in the dark iris of figure 4, and white iris of figure 1 . The wings in the two more detailed images are finely drawn; figure 1 displaying seven primaries and six to seven wing coverts, and figure 2 displaying five to six primaries as well as nine to ten greater wing coverts and six median wing coverts. Moreover, in figures 1 and 2, the detail is such that we can see that the periophthalmic area is grey with black markings and there is a short black eye stripe. Even in figure 3 the eye stripe is clearly visible. Despite these subtle discrepancies among the figures, many of which can be attributed to the different pigments used and the way they have aged, all four drawings appear to be of the same bird - the cockatoo given to Frederick II by the sultan.

There are two distinct species of cockatoo (genus Cacatua), which are often both erroneously referred to as Sulphur Crested Cockatoos: the Sulphur-crested Cockatoo

\footnotetext{
${ }^{24}$ Codex Ms. Pal. Lat 1071, fol. 18v.

${ }^{25}$ The black loral is non-existent in the cockatoos of genus Cacatua.
} 
(Cacatua galerita) and the Yellow-crested Cockatoo (Cacatua sulphurea). ${ }^{26}$ There are four recognised subspecies of Sulphur Crested Cockatoo: the Greater Sulphurcrested Cockatoo (Cacatua galerita galerita), native to Eastern Australia and Tasmania; the Fitzroy or Matthews Cockatoo (Cacatua galerita fitzroyi) - native only to the North coast of Australia around the Fitzroy River/Gulf of Carpentaria; the Triton Cockatoo (Cacatua galerita triton), as shown in figure 5, - native to Papua New Guinea and Irian Jaya; and the Eleanora Cockatoo (Cacatua galerita eleonora) native to the Aru Islands to the south of Irian Jaya (see figure 6 for range map). ${ }^{27}$ While Sulphur-crested Cockatoos measure 45 to 50 centimetres from beak to tail, Yellow-crested Cockatoos measure approximately 35 centimetres. ${ }^{28}$ All four of these smaller subspecies are native to Indonesia (in the areas east and northeast of the Java Sea: Bali, Timor-Leste and Timor, the Lesser Sunda Islands and on Sulawesi). The best known is the Citron-Crested cockatoo (Cacatua sulphurea citrinocristata), which is native only to the island of Sumba (see figure 7 for range map). ${ }^{29}$ All Yellowcrested Cockatoos and one subspecies of Sulphur-crested Cockatoo - the Eleanora Cockatoo - are native to spice-rich islands, which, while 'biologically an outpost of Australia', are closer to the coastlines of mainland Asia and therefore tied into South East Asian trade routes. This is demonstrated by the widespread use of a Malay word for the bird, 'kakatua.' Malay served as the trading lingua franca of the whole archipelago from the first millennium onwards. Today Greater Sulphur-crested Cockatoos are also found in Western Australia, Hawaii and Singapore and the Eleanor Cockatoo in the Kai Islands in Indonesia. These birds did not migrate, but were transported and introduced to these areas by humans. ${ }^{30}$

The four images of the cockatoo in De Arte are not drawn to scale. Although the artists drew the falcons and their handlers to scale, they did not do the same when it came to groups of birds on a single folio. This is aptly illustrated in figure 4 where the cockatoo is smaller than the female blackbird (phunerius). Due to this lack of proportion, it is impossible to accurately identify the species of Frederick's cockatoo according to its size. However, as noted previously, one of the advantages of studying the drawings in situ at the Vatican Library is that we have been able to focus on small details and analyse changes in pigment. ${ }^{31}$ Firstly, we should note that the periophthalmic area around the eye of the bird is grey and thus it is highly unlikely that Frederick's cockatoo was a Greater Sulphur-crested or Eleanora Cockatoo as they have white skinned periophthalmic rings. The other two subspecies of Sulphur-crested Cockatoo - the Fitzroy and Triton Cockatoos (see figure 5) - have a pale blue tinged periophthalmic ring, as do all four subspecies of Yellow-crested Cockatoo. ${ }^{32}$

\footnotetext{
${ }^{26}$ David M. Brown and Catherine A. Toft, 'Molecular systematics and biogeography of the cockatoos (Psittaciformes: Cacatuidae),' The Auk 116/1 (1999), 141-157.

${ }^{27}$ Edward John Mulawka, The Cockatoos: A Complete Guide to the 21 Species (Jefferson, USA: McFarland and Co., 2014), p. 58.

${ }^{28}$ Mulawka, The Cockatoos, 59. Both the Triton and Eleanor Cockatoos are smaller that the other two subspecies of Sulphur-crested Cockatoo.

${ }^{29}$ The others are: Cacatua sulphurea; Cacatua sulphurea abbotti; Cacatua sulphurea parvula.

${ }^{30}$ Andries Teeuw, 'The History of the Malay Language' in Modern Indonesian literature (Dordrecht: Springer, 1967), pp. 4-7; Mulawka, The Cockatoos, p. 44; Tim Low, Where Song Began: Australia's birds and how they changed the world (Australia: Penguin/Random House, 2014), p. 119; Dalton, 'A Sulphur-crested Cockatoo', p. 678.

${ }^{31}$ See for example: A. Baker, Common Medieval Pigments (2004) available from dscholarship.pitt.edu/11954/1/a-baker-04-pigments.pdf (accessed 27 March 2017).

${ }^{32}$ Mulawka, The Cockatoos, 46; 'Sulphur-crested Cockatoo factsheet' at https://australianmuseum.net.au/sulphur-crested-cockatoo, accessed 7 March 2017.
} 
Frederick's cockatoo was not a Citron-crested Cockatoo, as they have a distinctive orange crest and bright yellow cheek feathers, and is unlikely to have been a Fitzroy Cockatoo because, not only are they native only to the east coast of Australia, they have much taller crests than the one depicted on Frederick's cockatoo. Bearing in mind the shape of the crest, the blue/grey of the periophthalmic ring and the lack of a yellow tinged ear patch, Frederick's cockatoo was in all likelihood a Triton Cockatoo, as shown in figure 5, or one of the three subspecies of Yellow-crested Cockatoos that have a yellow crest. ${ }^{33}$ Although we may consider that it was more likely to have been a Yellow-crested Cockatoo, because of their western distribution closer to the trade routes discussed later in this article, we cannot take the identification further.

While we cannot make an exact identification in regards to the species or subspecies of Frederick's cockatoo, we can hazard a guess as to its sex. Both Sulphur-crested and Yellow-crested Cockatoo males have dark brown irises, while the iris of the Sulphurcrested female is a reddish brown and the iris of the Yellow-crested female is a distinct red. As we observed flecks of red pigment in the irises of all four images of the cockatoo in Codex Ms. Pal. Lat 1071, we feel able to suggest that the bird was female. Moreover, we are confident that this accurate rendition of the eye, which is not obvious unless one is close to a live bird, along with the highly detailed and fleshy toes in figure 2, suggest that the original sketches were of a healthy live bird. Frederick's cockatoo, which doesn't exhibit any signs of feather plucking (a habit among stressed captive parrots), is depicted standing on the ground in all of the illustrations. Although the bird's primary and/or secondary wing feathers could have been clipped to prevent flight, cockatoos do happily scavenge on the ground for long periods at a time. As cockatoos raise their crests when aggressive, fearful, surprised or as part of a courtship display, the recumbent crest indicates that Frederick's bird felt safe and calm. ${ }^{34}$

\section{The court of Frederick II and his relationship with the 'Sultan of Babylon'} Frederick II was heir to the Norman Kingdom of Sicily through his mother, Constance of Hauteville, the daughter of Roger II. His father, Henry of Hohenstaufen, was the son of the Western Emperor Frederick Barbarossa. In May 1198, at the age of three, he was crowned king at Palermo. By the age of four he was an orphan and by fourteen his minority ended. Frederick inherited a kingdom impoverished by intrigues and petty squabbles - a kingdom he was to rule for over half a century. ${ }^{35}$ In 1212 , after meeting Pope Innocent III in Gaeta, Frederick agreed on a future separation between his Sicilian and Imperial titles, with his wife, Constance of Aragon, acting as his regent in Sicily. In 1215 he was crowned 'King of the Romans', which made him ruler of the German lands of Europe, and in 1220 he was crowned Holy Roman Emperor by the new pope, Honorius III. During his reign Sicily - an island in the Mediterranean closer to Tunis than Rome - became the political centre of Europe.

\footnotetext{
${ }^{33}$ Subspecies classification: Triton Cockatoo (Cacatua galerita triton), Temmink, 1849; Cacatua sulphurea, Gmelin 1788; Cacatua sulphurea abbotti, Oberholser 1917; Cacatua sulphurea parvula, Bonaparte 1850.

${ }^{34}$ Mulawka, The Cockatoos, p. 61.

${ }^{35}$ For Fredericks early life see David Abulafia, Frederick II: A Medieval Emperor (London: Allen Lane, 1988). References in this article to the 2nd edition NY, NY: Oxford University Press, 1992), pp. 89-131.
} 
There has been much discussion amongst scholars about what kind of monarch Frederick was and the nature of his court. Frederick inherited a court in which knowledge was prized. His grandfather, Roger II, had nurtured a keen interest in geography, adding to the translations of Arabian geographies available at the time by entertaining and interviewing travellers. Roger's immediate heirs, William I and II, oversaw the translation of Greek mathematical and astronomical texts and by the 1220 s Aristotle's logical treatises and works on Metaphysics, Ethics, and natural philosophy were available in Latin. In two articles published in 1921 and 1922, Charles Haskins suggested that Frederick's court was not simply a centre of learning, but that the research and production necessary to produce works like De Arte implied there was a 'spirit of free inquiry and emancipation from authority'. Indeed, the terminology and classifications used in De Arte come from the merging of biological and astronomical observation with theological knowledge with roots in the twelfthcentury medical school of Salerno. ${ }^{36}$ Although Haskins pointed out that the rich intellectual life of Frederick's court did not infiltrate his kingdom's universities and there was no replication of the northern studia in Sicily, Ernst Kantorowicz suggested in his 1927 biography that Frederick II was not only a ruler ahead of his time, but that his court provided a foretaste of the Italian Renaissance. ${ }^{37}$ Since 1988 when David Abulafia's pointedly titled Frederick II: A Medieval Emperor was published, the general consensus amongst scholars has been that although Frederick was a remarkable man, he was very much of his age - a typical medieval ruler. ${ }^{38}$ Nevertheless, the emperor and the Renaissance are still linked in the popular imagination. For example, in a review of Sicily: Culture and Conquest, an exhibition at the British Museum in 2016, Frederick's court was described as 'the culmination of a Renaissance before the Renaissance'. ${ }^{39}$ The reviewer based his statement on the fact that Frederick's portraits in stone and on coins emulate Roman art and that texts produced by his court could be in Latin, Greek or Arabic. In fact, it is the word 'Arabic' rather than the notion of Renaissance that is the key to the cultural richness of Frederick's court, the presence of the Sulphur-crested Cockatoo, and the impetus behind the production of De Arte.

Although Sicily's ruling class were of the Latin Church, much of the population was Greek Orthodox or Muslim. Visitors noted that both Christians and Muslims endowed and ran Sicily's hospitals and almshouses, and women of both faiths were veiled. The

\footnotetext{
${ }^{36}$ Haskins, 'The 'De Arte', pp. 334-355; Charles H. Haskins, 'Science at the Court of the Emperor Frederick II,' The American Historical Review 27/4 (1922), 669-694, 684; Piero Morpurgo, 'Federico II e la Scuola di Salerno : filosofia della natura e politica scolastica della corte sveve' and Steven J. Williams, 'The Early Circulation of the Pseudo-Aristotelian Secretum secretorum in the West: the Papal and Imperial Courts' in 'Le scienze alla corte di Federico II, a special edition of Micrologus 2 (1994): pp. 199-214, 127-144; Also see Hubert Houben, Roger II of Sicily: A Ruler Between East and West 9 (Cambridge University Press, 2002). It is not known whether it was the imperial or papal court that initiated the circulation of Aristotle.

${ }^{37}$ Haskins, 'Science', pp. 670, 676 and 'The 'De Arte', pp. 339, 355. Also see Hubert Houben, Roger II of Sicily: A Ruler Between East and West 9 (Cambridge University Press, 2002); Ernst H. Kantorowicz, Kaiser Friedrich der Zweite, (Berlin 1927) and in English translation: Frederick II: 1194-1250 (London: Constable \& Co. Ltd, 1931). For discussion of Kantorowicz's views see Martin Ruehl, The Italian Renaissance in the German Historical Imagination, 1860-1930 (Cambridge University Press, 2015), p. 171.

${ }^{38}$ Abulafia, Frederick II: A Medieval Emperor.

${ }^{39}$ Jonathan Jones, 'Sicily: Culture and Conquest review - gods, monsters and multiculturalism,' The Guardian (18 April, 2016). Available from: http://www.theguardian.com/artanddesign/2016/apr/18/ sicily-culture-and-conquest-review-british-london-museum.
} 
island's churches were designed by Norman architects, influenced by Byzantine and built and decorated by Christians and Muslims. Their interiors, decorated in Arabic designs and Byzantine mosaics, encapsulated the rich culture that Frederick inherited. On the painted muqarnas ceiling of the Palatine Chapel in Palermo, constructed circa 1140, Frederick would have seen depictions of hunters with falcons, a common theme in Islamic art. ${ }^{40}$ Moreover, the palaces in Palermo where he spent his youth were modelled on those of North Africa. ${ }^{41}$ Although Islam was confined mainly to the west of Sicily by the time Frederick became king, he could read and write in Arabic, and his appreciation of science and philosophy brought him into constant contact with Islam. In 1212, the year Frederick and Pope Innocent III met in Gaeta, a famine exacerbated an ongoing conflict in the region of the Monreale estates and between Girgenti and the coast. What had been a series of sporadic skirmishes evolved into open revolt as Muslim guerrillas battled the ecclesiastical authorities and minted their own coins. ${ }^{42}$ In the summer of 1222 Frederick acted, taking steps to seize Saracen strongholds in Sicily and stop further aid arriving from Africa. Within a year Muslims were being deported from Sicily to Lucera and while Muslims continued to live on the Italian Peninsula, the history of Islam in Sicily effectively ended. ${ }^{43}$ Despite his role in routing the Muslim rebels, Frederick continued to respect the island's Islamic heritage, especially the art of falconry. This was much more than just a sport or form of hunting for Frederick, for in the Muslim world the falcon had a strong symbolic association with the idea of al-mulk or legitimate power. ${ }^{44}$ In 1222 Frederick moved his capital from Palermo to Foggio in Apulia across the peninsula from Naples. He built a palace in the Muslim enclave of Lucera to the northwest of Foggio and for the rest of his life spent as much time as he could in the area's hunting lodges. With the aim of attracting herons, cranes and other water birds, Frederick oversaw the digging of ditches to join the natural waterways in the grounds of his palace. The project was a success and birds were bred there specifically to attract and train falcons and other birds of prey. Frederick also kept water buffalo, sheep, goats, pigs and bees at his various palaces and bred horses, importing Barbary mares to improve bloodlines. Although his court was itinerant, Frederick maintained his management of his animals even when he was absent. He issued orders from afar to the courtiers in his palaces, ensuring his animals, especially his beasts of prey, were well cared for. ${ }^{45}$

\footnotetext{
${ }^{40}$ Runciman, The Sicilian Vespers, pp. 9-10; Virgilio M. Enamorado, 'Falcons and Falconry in AlAndalas', Studia Orientalia 111 (2011), 150-183 (p. 175). Also see: Jeremy Johns: 'Muslim Artists and Christian Models in the Painted Ceilings of the Cappella Palatina in Palermo' in Romanesque and the Mediterranean: Points of Contact across the Latin, Greek and Islamic Worlds c.1000 to c.1250, eds Rosa Bacile and John McNeil (London: Maney Publishing, 2015), pp. 59-89; M. Gelfer-Jørgensen, 'The Islamic Paintings in Cefalù Cathedral, Sicily,' Hafnia, Copenhagen Papers in the History of Art (1978), 107-168.

${ }^{41}$ Abulafia, Frederick II, pp. 145 - 148. For information on Frederick's interest in Greco-Roman architecture, see: Michael Greenhalgh, Marble Past, Monumental Present: Building With Antiquities in the Mediaeval Mediterranean (Leiden: Brill, 2009), pp. 439-442; Jean Castex, Architecture of Italy (Westport, CT: Greenwood Press, 2008), pp. 21-22.

${ }^{42}$ Abulafia, Frederick II, pp. 144, 186. For information about the Monreale estates, religious identity and dissent see: Jeremy Johns, Arabic Administration in Norman Sicily: The Royal Diwan (Cambridge: Cambridge University Press, 2002), pp. 185-192; David Abulafia, 'The End of Muslin Sicily' in Muslims Under Latin Rule, 1100-1300, ed. James M. Powell (Princeton NJ: Princeton University Press, 1990), 103-135.

${ }^{43}$ Amin Maalouf, The Crusades through Arab Eyes, trans. Jon Rothschild (London: Al Saqi Books, 1983), p. 227; Abulafia, Frederick II, pp. 145 - 148, 152.

${ }^{44}$ Enamorado, 'Falcons and Falconry in Al-Andalas', p. 166.

${ }^{45}$ Abulafia, Frederick II, pp. 145 - 148, 153-4, 253, 270; Richard F Cassady, The Emperor and the Saint (DeKalb, IL: Northern Illinois University Press, 2011), p. 211.
} 
In mid 1222, while Frederick was mustering forces against Muslim guerrillas, his wife Constance died. His second wife, Yolanda of Brienne, was heiress to the Kingdom of Jerusalem. Many historians have suggested that it was this marriage that led to Frederick's contact with the fourth Ayyubid sultan of Egypt, the Kurdish alMalik Muhammad al-Kamil (often referred to in the West as Meledin). ${ }^{46}$ However, Frederick's first contact with al-Kamil took place eight years before he married Yolanda. In 1217, one year before al-Kamil became sultan, Frederick sent an envoy to visit him and his brother al-Muazzam. After marrying Yolanda in 1225, Frederick sent another envoy to al-Kamil who reciprocated a year later by sending an embassy to Sicily under the auspices of the emir Fakhr Al-Din Ibn Al-Shhaykh. ${ }^{47}$ Fakhr al-Din confirmed that Frederick could speak and write Arabic perfectly and informed the sultan that not only did the emperor admire Islam, he was contemptuous of the barbaric West and the Pope of Rome. Fakhr al-Din became a confidant of the emperor and forged links that led to the emperor and sultan exchanging letters in which they discussed philosophy, the cosmos and the immortality of the soul. In the early autumn of 1227 Frederick sent a return embassy. The emperor's envoy, his bailli, Thomas of Acerra, took magnificent gifts to al-Kamil, including horses fitted with golden stirrups encrusted with jewels, ornaments, textiles and falcons. ${ }^{48}$ Middle Eastern rulers maintained menageries to display wealth and power, and this was a custom that Frederick adopted. Throughout their relationship, which was to last until the sultan's death in March 1238, Frederick and al-Kamil continued to exchange animals.

It must be emphasized that however rich the gifts exchanged by Frederick II and Sultan al-Kamil and however deep the intellectual discussions between them and their envoys, theirs was a diplomatic rather than a personal relationship. Despite this, it has often been suggested that the closeness of their relationship led to both leaders betraying their own people to some extent. At the Council of Lyon in 1245, Frederick was accused of being the 'amicissimus' (best friend) of Muslim rulers and this criticism continued to resurface. ${ }^{49}$ Moreover, both Muslim and non-Muslim historians have accused al-Kamil of collaborating with Frederick's Crusaders. The reason for such allegations is that in 1229 both men signed the Treaty of Jaffa and, after 88 years in Muslim hands, Jerusalem was handed back to the crusaders. In fact, the reasons behind the handover of Jerusalem are complex and still the subject of discussion. On the one hand, Frederick was under pressure to lead a crusade as the Papacy blamed him for the defeat of the crusader army by al-Kamil and his two brothers at Damietta in 1221 . On the other hand, al-Kamil had reasons why it suited him that Frederick should lead a crusade to Jerusalem and it is commonly alleged that he invited him to do so. Al-Kamil's brother, al-Mu'azzam Issa, the Sultan of Damascus and Jerusalem, had formed an alliance with the Khwarizmians in an attempt to stop him and the other

\footnotetext{
${ }^{46}$ Al-Kamil's full name was 'al-Malik al-Kamil Naser ad-Din Abu al-Ma'ali Muhammad'.

${ }^{47}$ Evidence for Frederick sending an envoy in 1225/6 in the Arabic Chronicle Kita $\bar{b}$ S $\overline{\text { lar }}$ al-Aba ${ }^{-}$ (History of the Patriarchs of Alexandria) in Hiroshi Takayama, 'Frederick II's crusade: an example of Christian-Muslim diplomacy,' Mediterranean Historical Review 25/2 (2010), 169-185 (pp. 170-1).

${ }^{48}$ Takayama, 'Frederick II's crusade', pp. 171-2; Maalouf, The Crusades, pp. 226-227; Charles Burnett, 'Images of Ancient Egypt in the Latin Middle Ages' in The Wisdom of Egypt: Changing visions through the Ages, eds Peter J. Ucko and Timothy Champion (Abingdon: Routledge, 2016), p. 69.

${ }^{49}$ Daniel G. König, Arabic-Islamic Views of the Latin West: Tracing the Emergence of Medieval Europe (Oxford: Oxford University Press, 2015), p. 284.
} 
brother, al-Ashraf Khalil, taking over his Syrian possessions. ${ }^{50}$ The resulting power struggle between the two sultans meant that al-Kamil could see advantage in Frederick gaining possession of Jerusalem. He probably hoped that under Frederick's rule, Jerusalem would be reinvigorated and able to provide a more effective buffer between Egypt and the growing threat from the Mongol armies. ${ }^{51}$

In the period before, during and after the handover of Jerusalem, emissaries of the sultan and the emperor engaged in carefully choreographed diplomatic rituals. There were delays, each altering the diplomatic power play between the two rulers and providing for ever-more extravagant gift exchanges. The first delay occurred when Frederick postponed the crusade after falling ill on his way to join the crusaders gathered in Brindisi. This infuriated Pope Gregory IX and by the time al-Kamil's reciprocal embassy arrived in January 1228, laden with gifts including mules and elephants, Frederick had been excommunicated. Two months later, Frederick's second wife died after giving birth to their son and so his fleet's departure from Brindisi was further delayed until the end of June. Frederick took over two months to sail to Syria, stopping in Corfu, Cephalonia, Crete, Rhodes and Cyprus. He landed at Acre in early September to the cheers of the crusaders, who presumed that a battle was inevitable. ${ }^{52}$ Al-Kamil sent more gifts to Frederick in Acre, which, according to contemporary English chroniclers, included precious metals, jewels, textiles and exotic animals, including an elephant. ${ }^{53}$ Yet, despite his generosity, al-Kamil's reaction to the emperor's arrival was tempered by the fact that his brother had died in March and al-Mu'azam's young heir was proving to be a pliable ally. Understanding that the sultan was no longer such an enthusiastic supporter of his claim to Jerusalem, Frederick sent him a series of letters. He reminded al-Kamil that he had encouraged him to come and although 'personally, neither Jerusalem nor anything else in Palestine is a goal worth struggling for', he feared 'losing my respect among the Franks' if he failed in his quest. ${ }^{54}$ In response and still playing for time, al-Kamil sent further gifts with Fakhr al-Din who, understanding that neither leader could afford to lose face, advised Frederick that the people would never accept loss of Jerusalem without a battle. In November 1228 Frederick led his army of less than 3000 men towards the port of Jaffa. ${ }^{55}$ Occupied with suppressing rebellion in Syria, Al-Kamil's available manpower was similarly diminished. Whether or not the two armies had

\footnotetext{
${ }^{50}$ Robert Irwin, 'The Rise of the Mamluks' in The New Cambridge Medieval History, vol. 5, ed. David Abulafia (Cambridge: Cambridge University Press, 1999), pp. 607-622 (p. 611). For information on alMu'zzam's conversion to the Hanalite rite, see Sabri Jarrar, 'Suq al Mar'ifa: An Ayyubid Hanbalite Shrine in al-Haram al-Sharif' in Muqarnas: An Annual on the Visual Culture of the Islamic World, Volume 15, ed. Gülru Necipoğlu (Leiden: Brill, 1998), pp. 71-101 (p. 73).

${ }^{51}$ For further information see, for example: Maher Y. Abu-Munshar, 'Sultan al-Kamil, Emperor Frederick II and the Submission of Jerusalem,' International Journal of Social Science and Humanity 3/5 (2013), 443-447.

${ }^{52}$ Hiroshi Takayama, 'Frederick II's crusade: an example of Christian-Muslim diplomacy,' Mediterranean Historical Review 25/2 (2010), 169-185 (pp. 165, 173-4); Andrew Jotischky, Crusading and the Crusader States (Upper Saddle River, NJ: Pearson Education, 2004), p. 262; Abulafia, Frederick II, pp. 145-148, 152, 167.

${ }^{53}$ Matthew Paris and Henry III's elephant,' Henry III Fine Rolls Project, www.finerollshenry3.org. uk/ redist/pdf/fm-06-2012.pdf; Roger of Wendover, Flores Historiarum in Takayama, 'Frederick II's crusade', p.174.

${ }^{54}$ Ibn Wasil, Mufarij al-Kurub fi Akhbar Bani Ayyub, vol. 4, ed. Hassanein Rabie (Cairo: Dar al-Kutub, 1972), 243; Abu-Munshar, 'Sultan al-Kamil, Emperor Frederick II and the Submission of Jerusalem', p. 444; Maalouf, The Crusades, pp. 224-7; Abulafia, Frederick II, pp. 182-183.

${ }_{55}$ Maalouf, The Crusades, p. 228.
} 
mustered merely to give the impression that a battle was about to take place, it served as a powerful face-saving statement. Without a drop of blood being spilt, the Treaty of Jaffa and Tell Ajul was signed, placing Jerusalem, Bethlehem and Nazareth under the rule of Frederick for a period of ten and a half years. ${ }^{56}$

On the 18 of March 1229 Frederick entered the Holy Sepulchre, wearing his crown as a Catholic emperor, confirming the title of King of Jerusalem he had borne since marrying Yolanda. Despite rumours to the contrary, a formal coronation did not take place. ${ }^{57}$ On 1 May he returned home, subsequently repelling the papal armies that had invaded his lands and forcing the pope to absolve his excommunication. Although Frederick never went to the Holy Land again, he continued to correspond with alKamil and his successors, his sons al-'Adil and al-Salıh, exchanging gifts - many of them large, fierce animals. ${ }^{58}$ By exhibiting such beasts, rulers displayed their power and international connections and, by caging and taming them, symbolised their ability to defeat and constrain enemies. ${ }^{59}$ In this the emperor and the sultans may have been competitors, yet they were also co-conspirators, boosting each other's collections. In 1233 al-Kamil sent an emissary, Salah al-Din, to Frederick to confirm their pact of 1229. This time the emissary brought various birds, including a rare gyrfalcon, described in De Arte as the best hawk for hunting. Once he returned from Gaeta, where he had been working to retrieve lands lost during the period of his excommunication, Frederick sent the sultan a white bear and a white peacock. This exchange suggests both rulers were upping the ante for both the gyrfalcon and the white bear would have been sourced from the far North. Indeed, because gyrfalcons were so rare and difficult to obtain in the medieval period, they were considered to be royal birds. The geographer and historian Ibn Sa'id al-Maghribi (1213-1286) recorded that the Egyptian Sultan paid 1,000 dinars for each gyrfalcon sourced from Iceland, described as 'an island west of Ireland' ${ }^{60}$ In his study of Frederick II, Ernst

Kantorowicz suggests that the sultan sent the emperor the white cockatoo in exchange for the white peacock, and this may well have been the case. ${ }^{61}$ While we cannot pinpoint the exact date or occasion when Frederick received the cockatoo, nor ascertain where it was kept or how long it lived, we can be certain that it would have had to be kept well away from the emperor's falcons. Even large parrots like Sulphurcrested Cockatoos are vulnerable to birds of prey. In the ninth century, a white cockatoo, belonging to the Chinese Emperor Xuanzong of Tang (Hsuan-tsung) was killed by a goshawk as it flew at a games board (which it was apt to do whenever the emperor was losing). ${ }^{62}$ Today, birds of prey are still used in Australia to regulate parrot colonies and in 2008 a trained eagle and falcon were employed in an attempt to

\footnotetext{
${ }^{56}$ For more about the handover of Jerusalem see Abu-Munshar, 'Sultan al-Kamil, Emperor Frederick II and the Submission of Jerusalem', pp. 445-6.

${ }^{57}$ Abulafia, Frederick II, pp. 186-187.

${ }^{58}$ Takayama, 'Frederick II's crusade', pp. 175-6; Mary Refling, 'Frederick's Menagerie,' unpublished conference paper, Second Annual Robert Dombrowski Italian Conference, Storrs, Connecticut, September 2005, p. 3. Ernst Kantorowicz, Frederick II translated by E. O. Lorimer (New York: E. Ungar Publishing co, 1931), p. 358.

${ }^{59}$ Refling, 'Frederick's Menagerie,' p. 3.

${ }^{60}$ Tara Carter, Iceland's Networked Society: Revealing How the Global Affairs of the Viking Age Created New Forms of Social Complexity (Leiden: Brill, 2015), p. 260.

${ }^{61}$ However, Haskins reports that the bear and peacock were sent to al-Ashraf sultan of Damascus in return for a planetarium. Haskins, 'Science', p. 678.

${ }^{62}$ Edward H. Schafer, 'Parrots in Medieval China' in Studia Serica Bernhard Karlgren Dedicata, eds SØren Egerod and Else Glahn (Copenhagen: Ejnar Munksgaard, 1959), pp. 271-282 (p.281).
} 
stop Sulphur-crested Cockatoos breaking the lights on the Arts Centre tower in Melbourne. ${ }^{63}$

The travelling zoo that accompanied Frederick's peregrinations after he returned from Jerusalem was reportedly a wondrous sight. In November 1231 Frederick's entourage entered Ravenna accompanied by 'elephants, dromedaries, camels, panthers, gerfalcons, lions, leopards, white falcons, and bearded owls'. In 1236 a similar view greeted the residents of Parma, where it impressed one observer, the young Salimbene di Adam. Salimbene, a Franciscan chronicler, later recorded seeing an elephant, camels, leopards and hawks. The birds of prey and occasionally even cheetahs were used to hunt along the route. ${ }^{64}$ In 1241 Richard of Cornwall, the brother of England's king and brother-in-law of Frederick, was introduced to the Emperor's elephant when passing through Cremona. There are drawings of some of these animals, including the elephant that Matthew Paris, an English Benedictine chronicler, sketched in the margin of his manuscript, and the ostriches, falcons and lion Villard de Honnecourt claimed to have drawn from life. ${ }^{65}$ Frederick also exchanged exotic fauna with other rulers. In 1235 Matthew noted that the emperor had sent Henry III a camel. The English king was known to appreciate exotic animals and in 1251 the king of Norway presented him with a polar bear, which swam in the Thames and caught fish while attached to a rope. ${ }^{66}$

Despite the stir that Frederick's menagerie caused, during the diplomatic visits leading up to his commercial treaty with the sultan of Tunis in 1231, it was noted that the emperor preferred receiving a rare book, bird or example of craftsmanship, rather than a large beast or luxury item. ${ }^{67}$ Scholarship remained high on the emperor's agenda and learning about birds and falconry in particular was a priority. In the preface to $D e$ Arte, Frederick acknowledged that he followed Aristotle 'the prince of philosophers', who had written nineteen books on animal life, but 'not in all things'. This was because, while the philosopher had no experience of falconry, Frederick was proud to admit 'we have loved and practised (falconry) all our life'. Frederick had taken particular note of the birds during his time in the Middle East and had adopted the Arabian method of hooding falcons. He brought in Egyptian experts to Apulia to oversee the incubation of ostriches' eggs in the sun, another phenomena he had marvelled at in his travels. He also ordered that blindfolded vultures be released near prey to ascertain whether they found their food by sight or by smell. He described the method and outcomes of the experiments involving both the ostriches and vultures in

\footnotetext{
${ }^{63}$ Low, Where Song Began, p. 114.

${ }^{64}$ Haskins, 'Science', p. 680; Abulafia, Frederick II, 153/4, p. 270.

${ }^{65}$ Matthew Paris, Chronica maiora, Part II, MS 16, fol. 151v, Parker Library, Corpus Christi College, Cambridge; Richard Cassidy and Michael Clasby, 'Matthew Paris and Henry III's elephant,' Henry III Fine Rolls Project, available from www.finerollshenry3.org.uk/redist/pdf/fm-06-2012.pdf. accessed 2 January 2016; Villard de Honnecourt, 'sketchbook', c. 1230-40, Ms Fr. 19093, Bibliothèque nationale de France, Paris, fols $18 \mathrm{v}$ and 24v. Despite Honnecourt's claim, to have drawn the lion from life, the work has visible compass marks. See, for example Jean A. Givens, Observation and Image-Making in Gothic Art (New York: Cambridge University Press, 2005).

${ }^{66}$ A.C. Borg, 'The Royal Menagerie' in The Tower of London: its buildings and institutions, ed. John Charlton (1978), 100; Michael Prestwich, The 'Wonderful Life' of the Thirteenth Century in Thirteenth Century England: Proceedings of the Durham Conference 1997 edited by Michael Prestwich, Richard Britnell, Robin Frame, (Woodbridge: Boydell \& Brewer, 1999), p. 164.

${ }^{67}$ Haskins, 'Science',' 678.
} 
chapters 10 and 23 of his De Arte. ${ }^{68}$ It was this latter kind of experiment that the Italian Franciscan, Salimbene di Adam, featured in his descriptions of 'Frederick's seven idiosyncrasies' in his chronicle. In it he alleged that Frederick fed two men a large meal and, after sending one hunting and the other to have a nap, disembowelled them in order to determine the effects that activity versus sleep had upon the digestion. Salimbene was a Guelf partisan and thus out to demonise Frederick. Nevertheless, however apocryphal his report, it does reflect the fact that Frederick was a ruler whose analytical drive and desire to understand the natural world could be taken to extraordinary lengths. ${ }^{69}$ Although many of Frederick's message to the Sultan of Cairo focused on matters of scholarship, his last, sent a few months before he died in December 1250, did not concern philosophy, animal husbandry or the wonders of the natural world. It was of a much more urgent diplomatic nature. The emperor despatched a messenger, disguised as a merchant, to urgently inform al-Salih that King Louis IX of France had decided to attack Egypt. ${ }^{70}$

\section{Southeast Asian Trade Routes and the trade in parrots}

Frederick II would have been familiar with the fact that Aristotle had labelled parrots as 'human tongued'. African parrots and Rose-Tinged and Alexandrine parakeets from India had been imported into the Roman Empire from the Classical period and their ability to talk meant that, although they were prized, they were also lampooned as raucous figures of fun. However, as the Empire's trade routes declined and parrots once again became rare in Europe, they became the focus of wonder rather than derision, and by the thirteenth century they were esteemed as special - even sacred. The 'Ebstorf Map', made in Saxony around 1235, is the earliest European map to portray a parrot. The body of Christ dominates the map, spanning the earth. At Christ's feet are the Pillars of Hercules and to the right of and below Christ's head is a parrot, thus locating India and reflecting the medieval belief that parrots were linked with this Earthly Paradise - India. ${ }^{71}$ In the Persian Empire parrots were also associated with Paradise and thought of as particularly wise with a way with words referred to as 'sugar talking'. ${ }^{72}$ To Frederick, who is more likely to have appreciated his cockatoo as a rare and fascinating specimen rather than a sacred creature, India would have been but a hazy concept. Nevertheless, he would no doubt have been intrigued, if not amazed, to learn that his white cockatoo was a species from a land so far east and so far south of there. Indeed, his cockatoo is likely to have come into the Middle East via China rather than directly to the country we now call India. By the third century A.D. coloured and white parrots from islands off what we now know as Indonesia had entered China and Tang Dynasty gardens and parks were stocked with exotic birds. ${ }^{73}$

\footnotetext{
${ }^{68}$ Haskins, 'Science', 687 and 'The 'De Arte,' 342. Also see: Jukka Salo, Pekka Niemelä, H. Laaksonen, 'Frederick II of Hohenstaufen, Bergmann`s rule and Aristotelian typology'. Ornis Fennica 68 (1991), 3335.

${ }^{69}$ Salimbene, da Parma, The chronicle of Salimbene de Adam, trans. Joseph L. Baird, Giuseppe Baglivi, and John Robert Kane (Binghamton, N.Y.: Medieval \& Renaissance Texts \& Studies, 1986), p. 355.

${ }^{70}$ Takayama, 'Frederick II's crusade,' 175-6; Mary Refling, 'Frederick's Menagerie,' unpublished conference paper, Second Annual Robert Dombrowski Italian Conference, Storrs, Connecticut, September 2005, p. 3; Ernst Kantorowicz, Frederick II translated by E. O. Lorimer (New York: E. Ungar Publishing co, 1931), p. 358.

${ }^{71}$ Dalton, 'A Sulphur-crested Cockatoo', p. 682.

${ }^{72}$ Kathleen Kulper, Islamic Art, Literature, and Culture (NY,NY: Encyclopaedia Britannica, 2010), 83. For further information see Amélie Kuhrt, The Persian Empire: A Corpus of Sources from the Achaemenid Period (Abingdon: Routledge, 2007).

${ }^{73}$ Schafer, 'Parrots in Medieval China', p. 275
} 
On the presentation of a Rose-crested Cockatoo to the Tang court, officials were told that it had come from a place five months away from Canton - suggesting it originated in the Moluccas. In the seventh century, diplomatic visitors from the Kingdom of Champa presented a parrot of five colours and a "white parrot" to the Tang court with the information that the birds had been "caught in the furthest part of Indonesia'. Chinese artists painted both parrots before they were returned to their homeland after 'complaining of the cold'. ${ }^{74}$ Although it is presumed that the 'white parrots' were cockatoos, the earliest surviving Chinese description of a Sulphur and/or Yellow-crested cockatoos' distinctive crest dates from the sixteenth century, noting that it was 'like a yellow mallow flower'. ${ }^{75}$

By the beginning of the seventh century, the majority of foreign merchants in Canton were Persians and Arabs and by the ninth they were numerous enough for the Chinese authorities to appoint one of them to maintain order and to 'administer' Islam. When trade was disrupted during the later ninth century by internal unrest in China, many of these foreign merchants moved to the west coast of the Malay Peninsula. By the end of the tenth century trade had revived, extending the links of Canton and its foreign merchants as far south-east as Java. The Chinese authorities went to great lengths to increase and regulate this trade in coral amber, pearls, shells, cotton textiles, timbers ensuring that it passed through only Canton and Ts'uan-chou. Although some goods and fauna, including parrots, coming into China would have come from islands east of Java, this was unknown and unchartered territory. The thirteenth-century Chinese author, Chau Ju-Kua explained that 'To the east of Java is the Great Eastern Oceansea, -where (the surface of) the waters to go downward; there is the kingdom of women. Still further to the east is the place where the wei-lü drains into the world from which men do not return'. ${ }^{76}$ Chau Ju-Kua also noted that 'Of all the wealthy foreign lands which have great store of precious and varied goods, none surpass the realm of the Arabs. Next to them comes Java, the third is Palembang'. He pointed out that it took Arab traders two years to make the round trip to China. ${ }^{77}$ These traders sent goods, and parrots, from the Indonesian archipelago west to join the cottons and silks of the Indian subcontinent, traded through the Indian Ocean to the Arabian Peninsula and on towards the Mediterranean. For much of the distance, goods travelled overland, along a route commonly known as the 'Silk Road'. In fact, this term is a nineteenth-century concept, 'situating Rome and China at either end, and largely ignoring the myriad of routes, markets and goods traded between and beyond these privileged locales'. ${ }^{78}$ By the thirteenth century, the rise of Islam in the Middle East had provided the merchants of the Eastern Mediterranean and Persia with a safe, common market place through which ran numerous silk roads.

\footnotetext{
${ }^{74}$ Dalton, 'A Sulphur-crested Cockatoo in fifteenth century Mantua', pp. 687-688.

${ }^{75}$ Schafer, 'Parrots in Medieval China', p. 277.

${ }^{76}$ Chau Ju-Kua, Chau Ju-Kua: 'His work on the Chinese and Arab Trade in the twelfth and thirteenth centuries, entitled Chi-fan-chi' (1225) Translated from the Chinese and annotated by Friedrich Hirth and W.W. Rockhill (St Petersburg: Imperial Academy of Sciences, 1911), pp. 15-19, 22, 26. See also Angela Schottenhammer, 'China's Emergence as a Maritime Power' in The Cambridge history of China, vol. 5, edited by John W. Chaffee and Denis Twitchett (Cambridge: Cambridge University Press, 2015), pp. 437-525. Ts'uan-chou was on the South China coast adjacent to northern Taiwan.

${ }^{77}$ Chau Ju-Kua: 'His work on the Chinese and Arab Trade, pp. 23- 24.

${ }^{78}$ Dalton, 'A sulphur-crested Cockatoo', p. 690.
} 
The court of al-Kamil, the fourth Ayyubid sultan of Egypt, was linked into this farreaching and complex web of material exchange. Under the Abbasid Caliphate, which had ruled all of West Asia and North Africa from 750 AD until about 1000, Baghdad in particular had become an important trade centre. Chau Ju-Kua reported that Baghdad, which he called 'Pai-ta', was 'extremely powerful and large', and that 'the towns and markets are cut by well-made streets, and the people live lavishly'. He noted that the people dressed in turbans and 'fine snow-white cotton' and that they prayed five times a day 'to Heaven'. He was impressed by reports that large ships from Arab countries regularly ferried goods to and from the ports of Andalusia. ${ }^{79}$ The recently translated Accounts of China and India by Abu Zayd al-Sirafi and other Arab chroniclers highlight the interconnectedness of this era, documenting exchanges with China, India and Central Asia as well as Charlemagne's European empire. This could explain why in Frederick's North African-style palaces in Lucera, archaeologists have unearthed Chinese celadon ware and other Eastern ceramics, which would have come into Europe via trading centres in the Middle East. ${ }^{80}$ In translating the letters in the Cairo Geniza, Shelomo Dov Goitein found evidence of both Jewish and Muslim merchants being involved in the East India trade. Muslim traders and envoys had been in situ since the 11th century, with Champa Muslims in Hainan having links with Islamic communities in Champa and in China. From 1200 a growing number of people emigrated from Southern Arabia to Indian Ocean ports. By the time al-Kamil became sultan, China's growing trade with Southeast Asia had led to the emergence of new trading ports in Champa, Sumatra, and Java and goods moving in both directions between Southeast Asia and China, the Indian Ocean region and the Middle East. Although this trade lessened from the mid thirteenth century due to circumstances within China and India, during the early thirteenth century Malay ports were exporting goods from other Southeast Asian destinations into China - including fauna described as 'white parrots'. ${ }^{81}$ There was another resurgence in trade in this area in the fifteenth century, which may have brought Mantegna his cockatoo.

\section{CONCLUSION}

The cockatoo in Frederick II's De Art suggests more than the fact an Australasian parrot reached Europe in the middle of the thirteenth century, it throws a light on what Amitav Ghosh calls one of 'those small, indistinguishable, intertwined histories' that crossed religious lines and was 'partitioned long ago'. ${ }^{82}$ Although lands east of the Wallace Line are today considered to have been the very last to have been discovered, this Eurocentric view is being increasingly challenged. Moreover, the case is being made that while India, China and the Arab world had a strong influence on maritime Southeast Asia, historiography has tended to emphasise the role of outsiders, thus

\footnotetext{
${ }^{79}$ Chau Ju-Kua: 'His work on the Chinese and Arab Trade, p. 35.

${ }^{80}$ Abulafia, Frederick II, 145 - 148; Marcus Milwright, An Introduction to Islamic Archaeology (Edinburgh: Edinburgh University Press, 2002), p. 165.

${ }^{81}$ Derek Heng, Sino-Malay Trade and Diplomacy from the Tenth through the Fourteenth Century (Athens OH: Ohio University Press, 2009), pp. 163, 224; Jan Wisseman Christie, 'Javanese Markets and the Asian Sea Trade Boom of the Tenth to Thirteenth Centuries AD,' Journal of the Social and Economic History of the Orient 41/3 (1998), 344-381; Geoff Wade, 'An Asian Commercial Ecumene' in Offshore Asia: Maritime Interactions in Eastern Asia Before Steamships (Singapore: ISEAS Publishing, 2013), pp. 76-112 (pp. 88-9). Also see: Abu Zayd al-Sirafi, Accounts of China and India and Ahmed Ibn Fadlan, Mission to the Volga, in Two Arabic Travel Books (New York/London: New York University Press), 2014.

${ }^{82}$ Amitav Ghosh, In an Antique Land (NY, NY: Vintage Books, 1992), p. 339.
} 
downplaying the maritime achievements of indigenous Southeast Asians. ${ }^{83}$ In the thirteenth century, just as in the fifteenth when Mantegna painted his cockatoo, Europe lay on the periphery of the complex trading network that originated in the Afro-Eurasian world-system with Asia being the source of luxury goods. Sultan alKamil may not have been aware of the exact place cockatoos came from but he would have been aware that they came from the distant Indies, a place drawn into a complex trading web that brought goods by sea and overland from China into trading posts and the cosmopolitan cities in his domain. To al-Kamil, the cockatoo was a rare, sociable and gifted bird from afar - a fitting gift for the Holy Roman Emperor.

\section{University of Melbourne and Institutum Romanum Finlandiae}

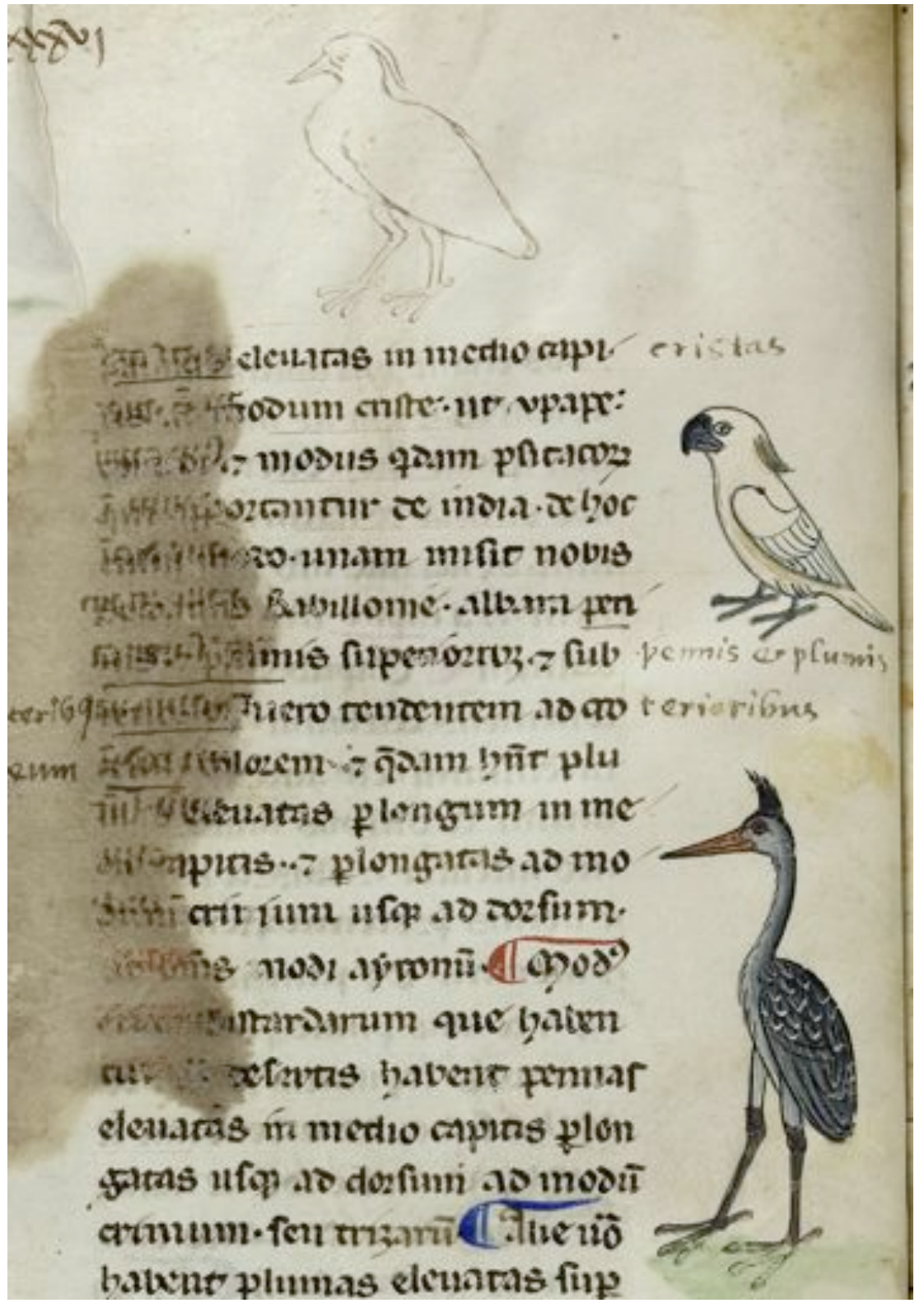

Figure 1: Codex Ms. Pal. Lat 1071, folio 18v (C [2018] Biblioteca Apostolica Vaticana).

\footnotetext{
${ }^{83}$ Jennifer L. Gaynor, 'Ages of Sail, Ocean Basins, and Southeast Asia,' Journal of World History 24/2 (2013), 309-333.
} 


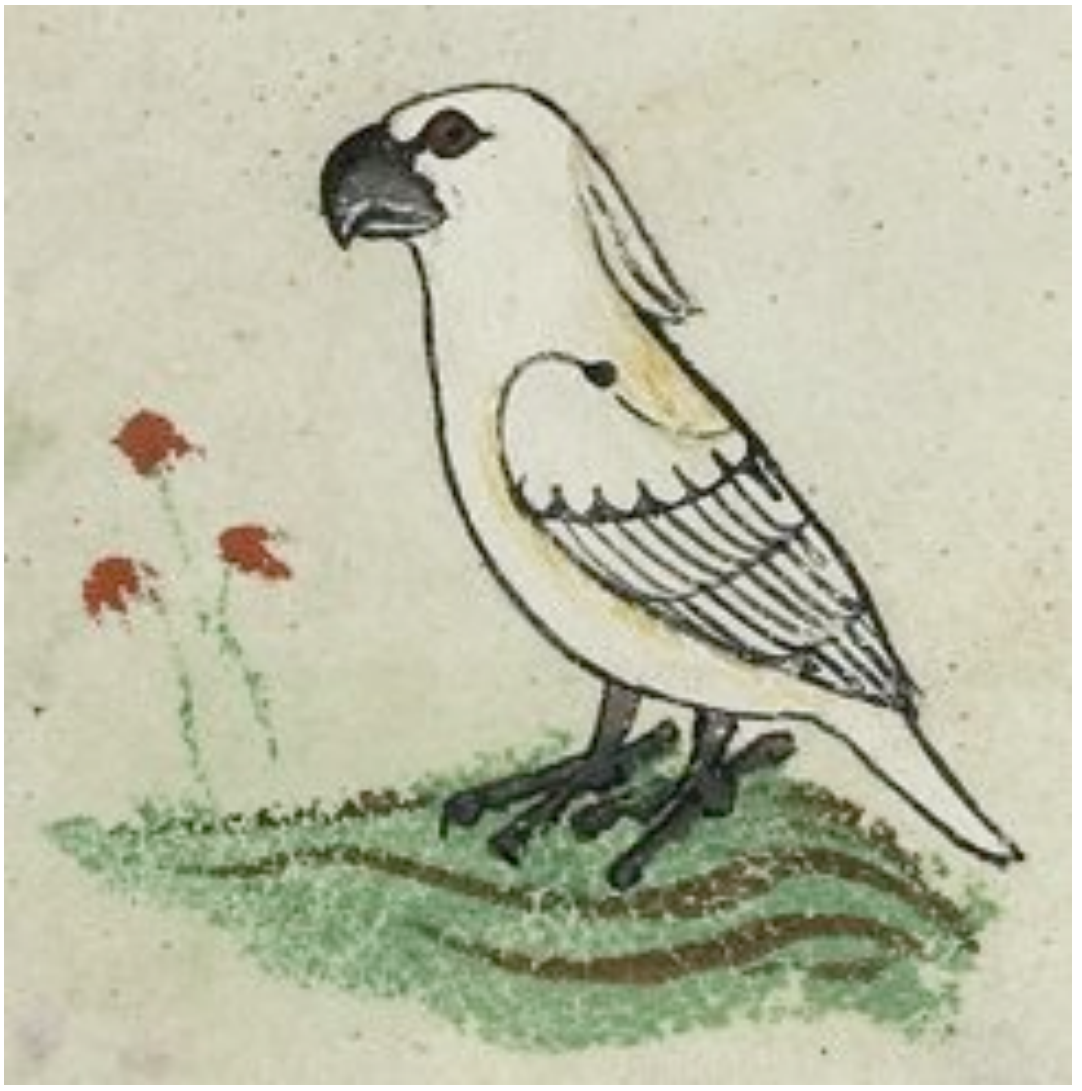

Figure 2: Codex Ms. Pal. Lat 1071, folio 20r (C) [2018] Biblioteca Apostolica Vaticana).

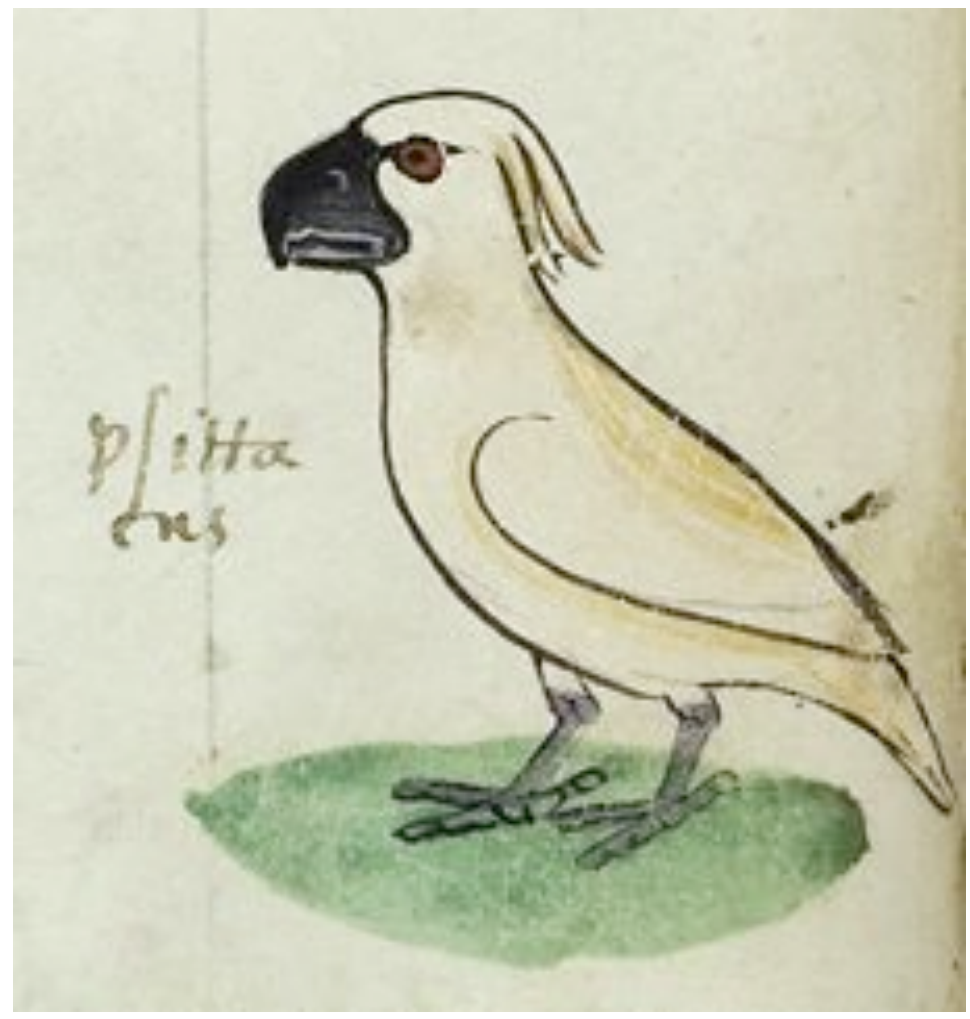

Figure 3: Codex Ms. Pal. Lat 1071, folio 20v (C [2018] Biblioteca Apostolica Vaticana). 
@ C Heather Dalton, Jukka Salo, Pekka Niemelä and Simo Örmä.

This is the 'accepted manuscript'. For high resolution colour images see article published in Parergon 35/1 (June 2018): 35-60.

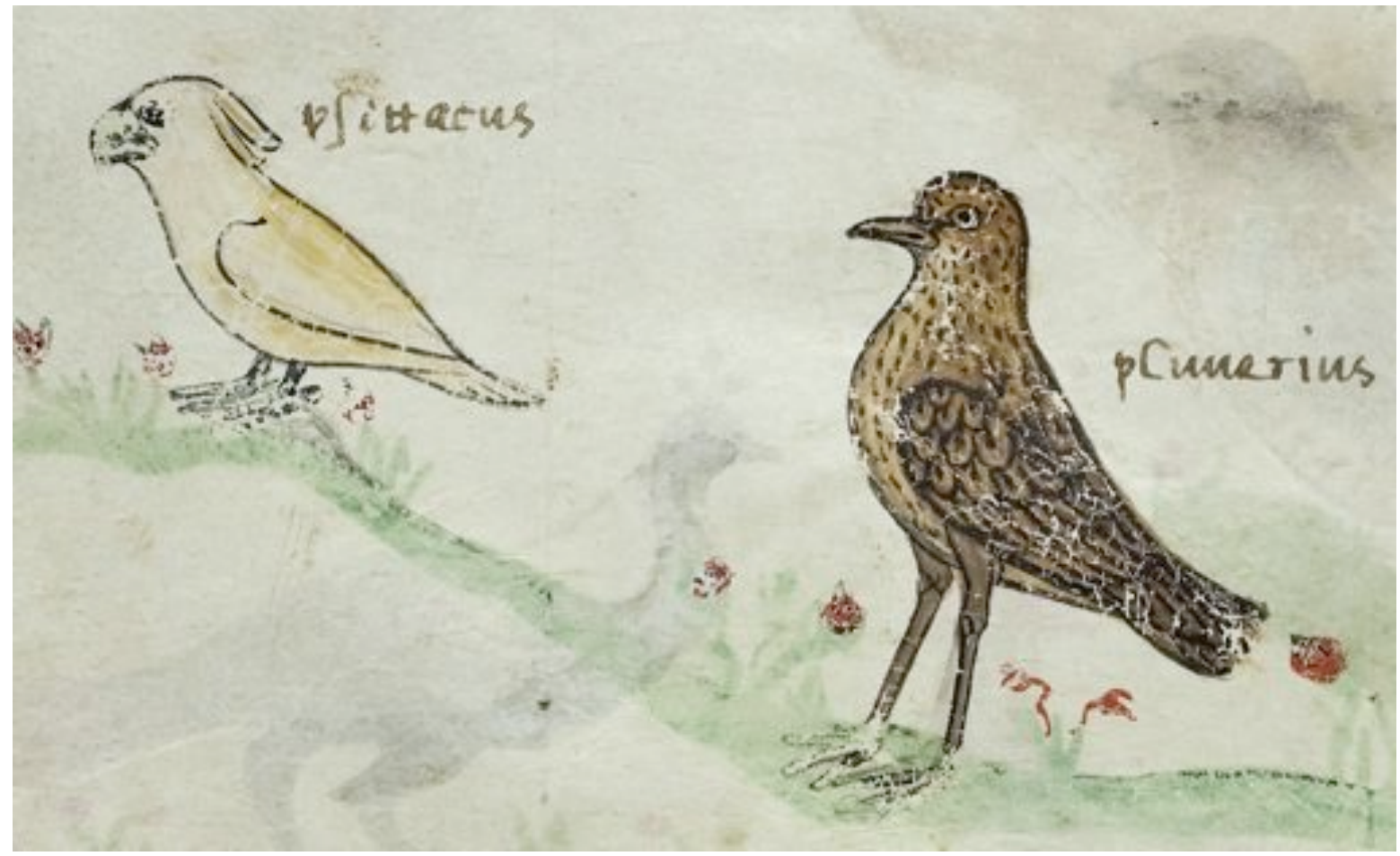

Figure 4: Codex Ms. Pal. Lat 1071, folio 26v (C [2018] Biblioteca Apostolica Vaticana).

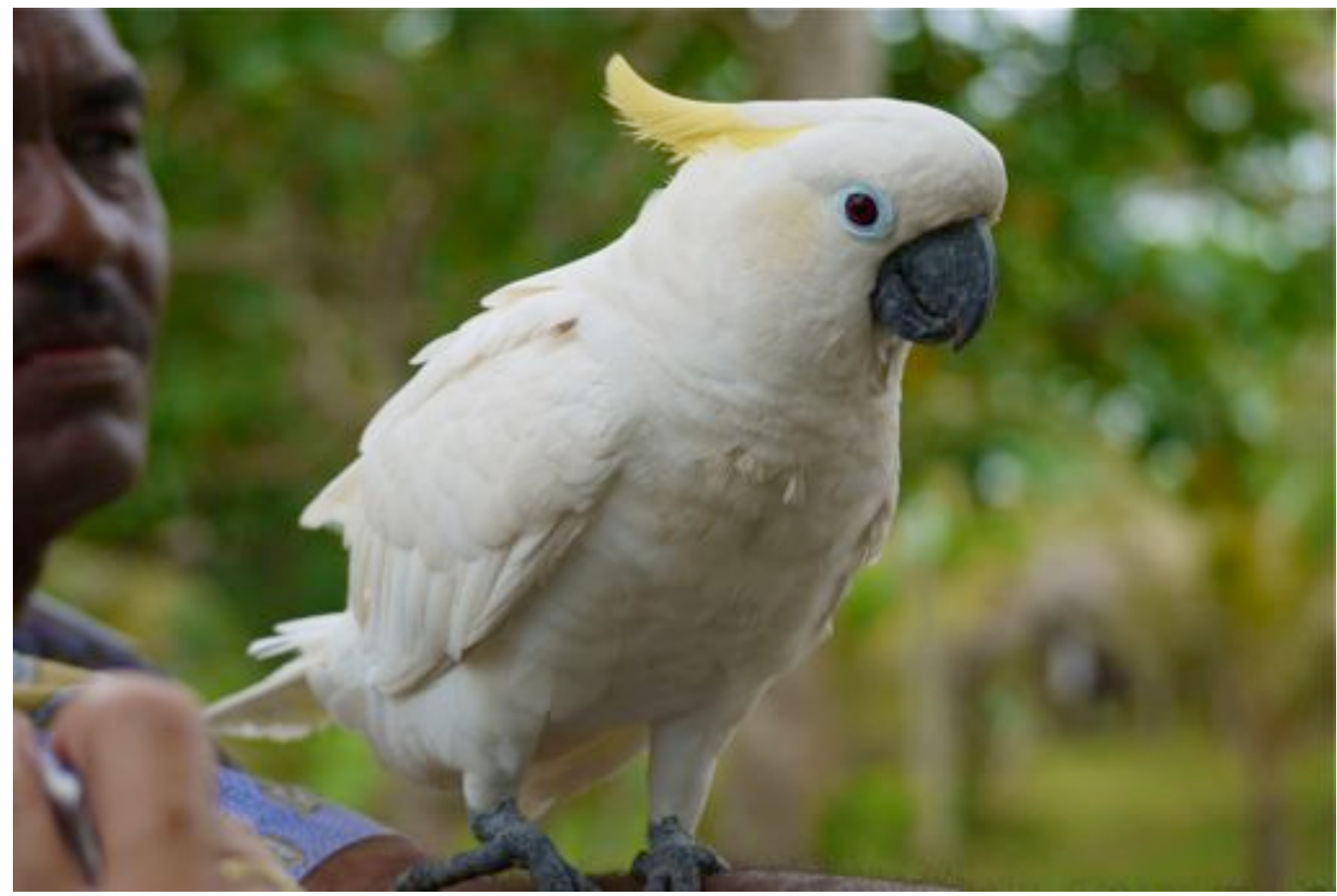

Figure 5: Female Triton Cockatoo (C.galerita triton), Trobriand Islands, Kiriwina, Papua New Guinea 2009, photograph (C Rita Willaert). 


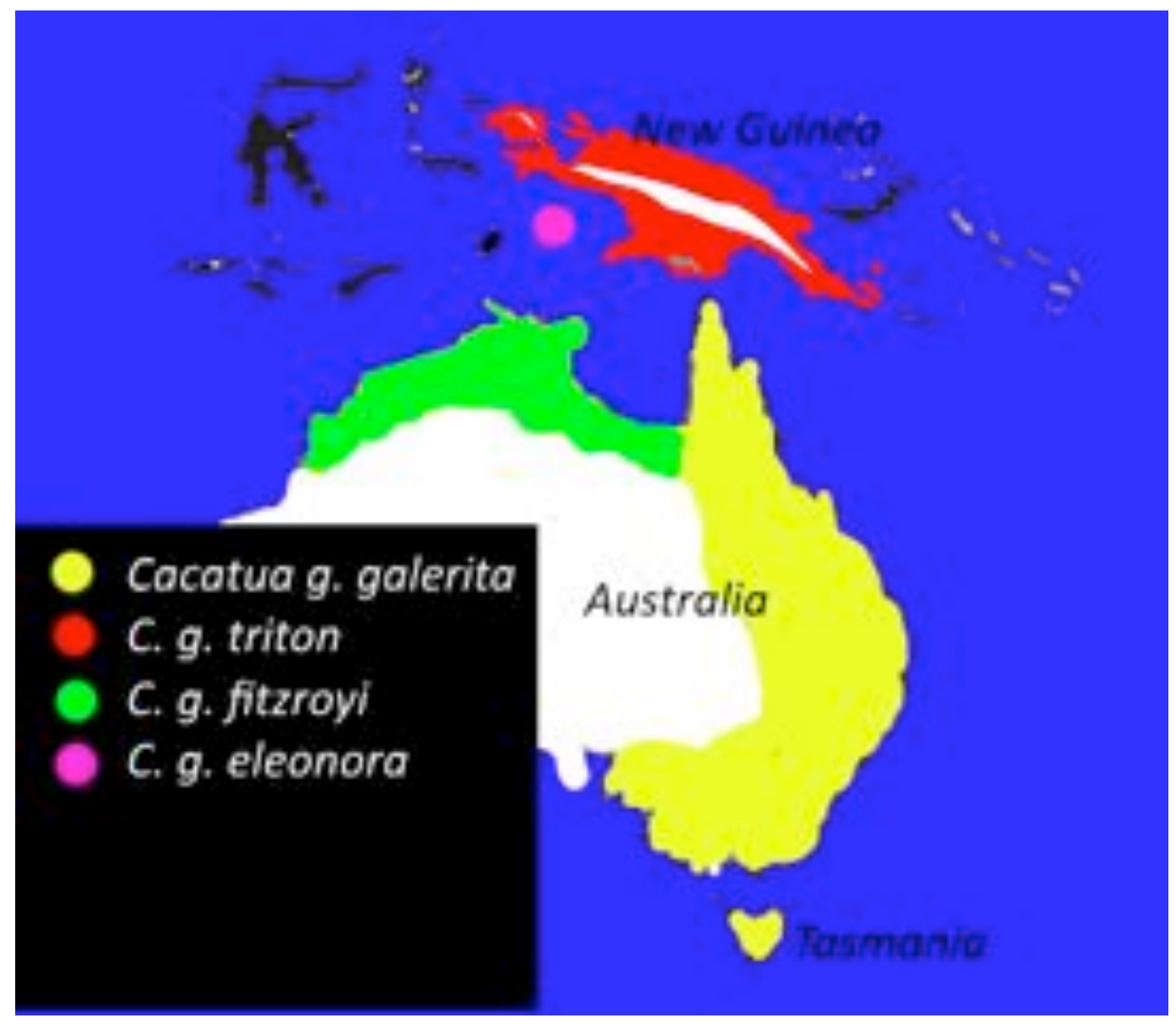

Fig. 6: Range of the four sub-species of Sulphur-Crested Cockatoo (Cacatua galerita). (C) authors, modified from Joseph M. Forshaw, Parrots of the World (Princeton NJ: Princeton University Press, 2010).

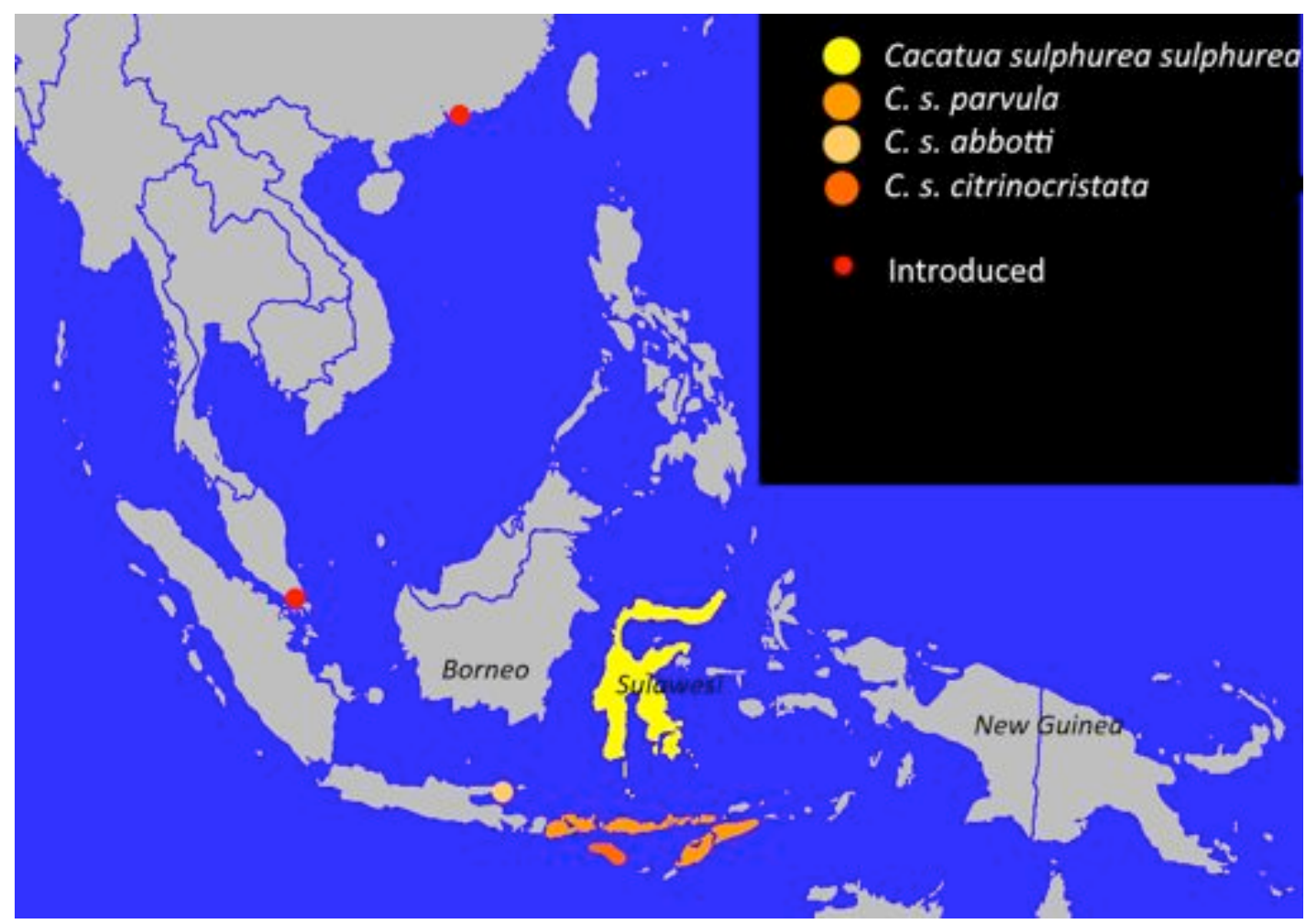

Fig. 7: Range of the four subspecies of Yellow-crested Cockatoo (Cacatua sulphurea). (C) authors). 